\title{
Effect of Seed Rate and Irrigation Interval on Yield Components and Yield of Bread Wheat (Triticum aestivum L.) at Mekane Selam District, South Wollo, Ethiopia
}

\author{
Nuru Seid Tehulie* Taminaw Zewdie \\ Department of Plant Science, College of Agriculture and Natural Resource, Mekdela Amba University, \\ Ethiopia \\ Tulu Awulia, Ethiopia
}

\begin{abstract}
Determination of optimum seed rate and planning suitable irrigation strategy are important practices to increase productivity of wheat under irrigation. Thus, a study was undertaken to determine the effects of irrigation intervals $\left(5,8,11\right.$ and 14 days) and seed rate $\left(75,100,125\right.$ and $\left.150 \mathrm{~kg} \mathrm{ha}^{-1}\right)$ on yield components and yield of bread wheat during 2019 cropping season (November to April). Wheat variety ADEL-6 was used as test crop. The experimental design was split plot design with three replications using irrigation interval as the main plot factor and seed rate as sub-plot factor. Results showed that the interaction effect of irrigation interval and seed rate had highly significant $(\mathrm{p}<0.01)$ effect on number of total tillers, effective tillers, grain yield, aboveground dry biomass yield, straw yield and harvest index. The highest number of total tillers (54.33) and effective tillers (49.33) per $0.5 \mathrm{~m}$ mid length row were obtained from the seed rate of $150 \mathrm{~kg} \mathrm{ha}^{-1}$ with irrigation interval of 5 days. On the other hand, the highest grain yield $\left(5.40 \mathrm{t} \mathrm{ha}^{-1}\right)$, the highest biomass yield $\left(13.34 \mathrm{tha}^{-1}\right)$ and the highest straw yield $\left(7.95 \mathrm{t} \mathrm{ha}^{-1}\right) \mathrm{were}^{-}$ obtained from seed rate of $100 \mathrm{~kg} \mathrm{ha}^{-1}$ and irrigation interval of 11 days which were statistically at par with the seed rate of $100 \mathrm{~kg} \mathrm{ha}^{-1}$ and irrigation interval of 8 days. The partial budget analysis also showed that the highest net benefit (37375 Birr ha-1) was recorded from the combination of seed rate of $100 \mathrm{~kg} \mathrm{ha}^{-1}$ and irrigation interval of 11 days followed by seed rate of $100 \mathrm{~kg} \mathrm{ha}^{-1}$ and irrigation interval of 8 days with net benefit of $34156 \mathrm{Birr}^{-}$ ${ }^{1}$. Thus, from the result of the study, it can tentatively be concluded that use of $100 \mathrm{~kg} \mathrm{ha}^{-1}$ seed rate and irrigation interval ranging from 8 to 11 days can improve the productivity of bread wheat in the study area.
\end{abstract}

Keywords: Field capacity, irrigation frequency, seed rate

DOI: $10.7176 / \mathrm{JBAH} / 11-1-02$

Publication date: January $31^{\text {st }} 2021$

\section{Introduction}

Wheat (Triticum aestivum L.) is one of the important grain crops produced worldwide and is a staple food for about one third of the world's population. Wheat flour has many uses, but its main use is to make bread, a staple food for many people around the world (Hussain and Shah, 2002). Important wheat producing countries include China, India, United States, Russia and France. In 2010 the estimated world production was 650,881,002 metric tons (FAOSTAT, 2010), which corresponds to about $94 \mathrm{~kg}$ per person (in 2010 the world had about 6.9 billion persons). Wheat is primarily used as a staple food providing more protein than any other cereal crop (Iqtidar et al., 2006). Bread wheat (Triticum aestivum) accounts for more than $90 \%$ of global wheat production and is grown on a substantial scale (over 100,000 ha) in more than 70 countries on 5 continents (Lantican et al., 2005).

Ethiopia is the second largest producer of wheat in Sub-Saharan Africa, following South Africa (White et al., 2001). Wheat is an important cereal crop in Ethiopia; it ranks third in terms of area after teff and maize, and second after maize in terms of productivity (FAO, 2005). However, the productivity of wheat in Ethiopia is much lower than the yields of other wheat producing countries of the world (White et al., 2001). Wheat is one of the various cereal crops largely grown in the highlands of Ethiopia and it is produced largely in the southeast, central and northwest parts of the country. However, wheat yield in Ethiopia is low as compared to the attainable yield of $5 \mathrm{t}$ $\mathrm{ha}^{-1}$ (MoA, 2012). Various biotic and abiotic factors are responsible for this low yield. Cultivation of unimproved low yielding varieties, insufficient and erratic rainfall, poor agronomic practices, diseases and insect pests are among the most important constraints to wheat production in Ethiopia (Dereje and Yaynu, 2000).

Seed rate plays a vital role for optimum plant densities which is a pre-requisite for increased seed yield. Higher seed rate produces more plants in unit area resulting in less intra-crop competition thereby affecting the yield and production cost. On the other hand, lower seed rate may reduce the yield drastically. Solomon et al. (2003); and Ozturk and Aydin (2004) also found yield reductions of 79.7\% and $65.5 \%$ when water stress was imposed either at earlier stages or at grain formation, respectively. Optimum seeding rate is considered as an important management factor for improving yield of wheat. It is of particular importance in wheat production because it is under the farmers control in most cropping systems. Baloch et al. (2010) reported that $150 \mathrm{~kg}$ seed $\mathrm{ha}^{-1}$ produced higher grain yield. In Ethiopia seed rates ranging from 125 to $175 \mathrm{~kg} \mathrm{ha}^{-1}$ are recommended for different varieties of bread wheat (MoA, 2009). 
Irrigation frequency has a significant influence on growth and yield of wheat. Besides rainfall, land type and soil texture are two important factors that determine the status of soil moisture. In light textured soil with high infiltration rate, wheat crop is more vulnerable to moisture stress. Mid-term drought around the heading period is more common. Recently, numerous studies dealing with crop production and water use efficiency under irrigation showed that proper irrigation intervals can increase crop yield, by improving soil water condition and their water use efficiency (Richards et al.2002).

Recently in Mekane Selam area wheat is growing under irrigation condition. Even though; adapted wheat varieties were released in the area with recommended seed rates, agro pastoralists in the area are usually apply their specific seed rates and irrigation water frequency for various reasons. Due to these reason production and productivity of irrigated wheat is low as compared to optimum irrigation applied yield. In these observed fact, proper irrigation water management and use of proper seed rate are highly important to improve wheat yield under agro pastoralist field. Although; there is huge potential to produce wheat under irrigation, the necessary agronomic recommendations are lacking.

Thus, this study was conducted with objective of assess the effect of seed rate and irrigation intervals on yield components and yield of bread wheat.

\section{Materials and Methods \\ Description of the Study Site}

The study was conducted in Northern high land Ethiopia, Amhara Regional State, Mekane Selam district. The area is located at $10^{\circ} 45^{\prime} \mathrm{N}$ latitude and $38^{\circ} 45^{\prime} \mathrm{E}$ longitudes and an altitude of $1827 \mathrm{masl}$. The study was conducted in 2019 crop season Mekane Selam district. The main agricultural activities are carried out mixed crop livestock production system is found in both high and low land areas of south wollo zone. The highland mixed crop livestock production system is largely based on intensive cultivation of cereals, pulses, tubers, vegetables and same oil crops. According to Ethiopian agro-ecological classification the area is grouped under weina dega with the major soil type vertisols and the most dominate land cover taken by cultivated land.

\section{Description of Experimental Materials}

The wheat variety ADEL-6 obtained from Werer Research center was used as test crop. It was released by WARC/EIAR in 2013. It is for irrigated lowlands possess high grain yield of 5-6 tha- ${ }^{1}$ good end use quality and tolerant to heat and salinity (ICARDA, 2017). The seed is certified and its germination was (98\%) with $99 \%$ purity. Diammonium phosphate $\left(18 \% \mathrm{~N}\right.$ and $\left.46 \% \mathrm{P}_{2} \mathrm{O}_{5}\right)$ and Urea $(46 \% \mathrm{~N})$ were used as source of fertilizers.

\section{Treatments and Experimental Design}

The experiment was laid out on a split-plot design comprising two factors viz. irrigation intervals as main-plot factor and seed rate as sub-plot factor. The main-plot factor had four levels, namely; 5 days, 8 days, 11 days and 14 days interval and sub plot had four levels, namely; 75, 100, 125 and $150 \mathrm{~kg} \mathrm{ha}^{-1}$. The treatment combinations were sixteen (16) treatments with three replications.

\section{Experimental Procedures and Field Management}

Land preparation started at end of November, 2019. Tractor with conventional land preparation implements, were used for plowing and disking. Each treatment was applied to a plot area of $5.4 \mathrm{~m}^{2}$ consisting of 6 rows of $3 \mathrm{~m}$ long and $1.8 \mathrm{~m}$ width with $0.3 \mathrm{~m}$ row spacing. The spacing between plots and blocks were $0.5 \mathrm{~m}$ and $1 \mathrm{~m}$, respectively. The one edge row at both sides and $0.3 \mathrm{~m}$ row length from both sides of row endings were left to be a border to avoid the border effects for the whole plot. Then, four rows with plot size $2.4 \mathrm{~m}$ by $1.2 \mathrm{~m}\left(2.88 \mathrm{~m}^{2}\right)$ were used as net plot.

Wheat variety ADEL-6 seed was used from Werer research center. The seed were measured and bag for each seed rate treatments. Each sub plot was 6 rows plot $^{-1}$ with $0.3 \mathrm{~m}$ apart and $3 \mathrm{~cm}$ hull length. Sowing was done by human labor with drilling two weeks after land preparation; at mid November 2019. DAP fertilizer were applied at sowing time at the rate of $50 \mathrm{~kg} \mathrm{ha}^{-1}$ by human labor were broadcasted and Urea $150 \mathrm{~kg} \mathrm{ha} \mathrm{g}^{-1}$ was also applied by split application; half 20 days after sowing (DAS) and the remaining half at booting stage uniform dose to the experimental plots.

Irrigation water was applied by furrow and two free irrigation were given for all treatments uniformly before starting irrigation intervals treatments. Irrigation water flow rate in to treatment plot was controlled by partial flume for each duration. With a head $(Z)$ of $18 \mathrm{~cm}$ and it has $12.3 \mathrm{l} / \mathrm{se}$ discharge rate at field capacity level.

Irrigation treatments were started 21days later after sowing or 14 days after emergence on this stage the wheat plant which were $15 \mathrm{~cm}$ long of seedling at initial stage. Due to these facts irrigation treatment (application schedule) were started on reference evapotranspiration (ETo), the plant were at seedling stage namely grass cover. Hence; the treatment were treated as per schedule that were planed $(5,8,11$ and 14) days interval. During each application, it was treated to a best earthling level. 
Irrigation treatments was found that maximum irrigation water was applied for 5 days interval that received maximum of 11 irrigations when compared with the 14 days interval which was received a maximum of 4 irrigations. On the other hand, 8 days interval and 11 days intervals treatments in the study experiment others agronomic practices were applied uniformly except two treatment factors, received a maximum of 7 and 5 irrigations, respectively, within the growing period.

\section{Crop Data Collected}

Phenological and Growth Parameters

Days to 50\% heading (DH): Days to heading was recorded by counting number of days from the date of sowing until when $50 \%$ of the plants in a plot produced spikes above the sheath of the flag leaf that was determined by visual observation.

Days to $90 \%$ physiological maturity (DPM): Days to physiological maturity was recorded by counting the number of days from date of sowing until when $90 \%$ of the plants changed green colour to yellowish, as indicated by senescence of the leaves as well as free threshing of seeds from the glumes when pressed between the thumb and the forefinger.

Plant height (PH): It was measured in $\mathrm{cm}$ from ground level to the top of the spike excluding the awns from ten randomly pre-tagged plants in the net plot at maturity.

Spike length (cm): It was measured from the bottom of the spike to the tip of the spike excluding the awns from 10 randomly taken spikes from the net plot.

Yield Components and Yield

Number of tillers (NT): The number of tillers was counted from $0.5 \mathrm{~m}$ length from two places in the net plot and then averaged

Number of productive tillers: The number of tillers bearing spikes was counted at the time of harvest per 0.5 meter length from two places of the net plot area and then averaged

Number of kernels per spike: The mean number of kernels per spike was computed as an average of 10 randomly taken spikes from the net plot area.

Thousand kernels weight (g): thousand kernels weight was determined based on the weight of 1000 kernels sampled from the grain yield of each net plot by counting using electronic seed counter and weighed with electronic sensitive balance. Then the weight was adjusted to $12.5 \%$ moisture content.

Aboveground dry biomass ( $\left.\mathbf{t ~ h a}^{-\mathbf{1}}\right)$ : the aboveground dry biomass was determined from plants harvested from the net plot area after sun drying to a constant weight and converted to tons per hectare.

Grain yield (GY): grain yield was taken by harvesting, sun-drying and threshing the grain from the net plot area. The yield was adjusted to $12.5 \%$ moisture content.

Straw yield (StY): Straw yield was obtained as the difference of the total above ground dry biomass and grain yield.

Harvest index (HI): It was calculated on a plot basis as the ratio of grain yield to the aboveground biomass yield and expressed as a percentage

$\mathrm{HI}(\%)=\frac{\text { Grain yield } / \text { plot }}{\text { Aboveground dry biomass } / \text { plot }} \times 100$

Data Analysis

All data collected were subjected to analysis of variance (ANOVA) procedure using GenStat $15^{\text {th }}$ edition software (GenStat, 2012). Comparisons among treatment means with significant difference for parameter was done by using Fisher's protected Least Significant Difference (LSD) test at 5\% level of significance.

\section{Results and Discussion}

\section{Phenological and Growth Parameter of Wheat}

Days to heading

Days to $50 \%$ heading was not significantly affected by the main factor of irrigation interval and seed rate and interaction effect of irrigation interval and seed rate. The longest days to $50 \%$ heading (49.33 days) was recorded for 5 day irrigation interval and at $75 \mathrm{~kg} \mathrm{ha}^{-1}$ seed rate (49.58) (Table 1). The dalliance in days to heading with frequent irrigation interval may be due to excessive frequency of irrigation which was 11 times applied during the growth period which enhanced vegetative growth.. Moreover, the delayed heading with the lowest seed rate might be due to less competition for growth resources within plants. 
Table 1 Main effect of irrigation interval and seed rate on plant phenology, growth parameters and yield components of bread wheat

\begin{tabular}{|c|c|c|c|c|c|c|}
\hline Treatment & $\mathrm{DH}$ & $\mathrm{DM}$ & $\mathrm{PH}$ & SLpS & $\mathrm{KpS}$ & $\overline{\mathrm{SL}}$ \\
\hline \multicolumn{7}{|c|}{ Irrigation Intervals (days) } \\
\hline 5 & 49.33 & 81.42 & 63.87 & 13.67 & 27.92 & 5.92 \\
\hline 8 & 47.92 & 81.75 & 61.13 & 13.42 & 30.33 & 6.32 \\
\hline 11 & 47.17 & 79.58 & 64.08 & 13.75 & 30.25 & 6.42 \\
\hline 14 & 47.92 & 80.50 & 61.73 & 13.33 & 29.17 & 5.78 \\
\hline $\operatorname{LSD}(5 \%)$ & NS & NS & NS & NS & NS & NS \\
\hline \multicolumn{7}{|c|}{ Seed rate $\left(\mathrm{kgha}^{-1}\right)$} \\
\hline 75 & 49.58 & 81.92 & 61.70 & 13.42 & 29.08 & 6.37 \\
\hline 100 & 46.92 & 80.75 & 63.32 & 13.83 & 30.25 & 6.07 \\
\hline 125 & 47.83 & 80.25 & 62.23 & 13.67 & 29.00 & 6.03 \\
\hline 150 & 48.00 & 80.33 & 63.57 & 13.25 & 29.33 & 5.97 \\
\hline $\operatorname{LSD}(5 \%)$ & NS & NS & NS & NS & NS & NS \\
\hline$\overline{\mathrm{CV}}(\%)$ & 5.79 & 2.52 & 6.71 & 5.90 & & \\
\hline
\end{tabular}

LSD $(5 \%)=$ least significant difference at 5\% probability level, CV $(\%)=$ coefficient of variation in percent, NS = non significant, $\mathrm{DH}=$ day to heading, $\mathrm{DM}=$ day to maturity, $\mathrm{PH}=$ plant height $(\mathrm{cm}), \mathrm{SLpS}=$ number of spikelets per spike, NKPS = number of kernels per spike and SL= spike length.

Days to $90 \%$ physiological maturity

The result showed that, irrigation intervals and seed rates had no significant influence on days to $90 \%$ physiological maturity. The result showed that delayed in physiological maturity (81.92 days) was recorded at $75 \mathrm{~kg} \mathrm{ha}^{-1}$ and when irrigation was applied at 8 days interval. The delayed day to physiological maturity with the lowest seed rate might be enhanced vegetative growth due to less intra specific competition.

\section{Plant height}

The analysis of variance revealed that the two main factors of irrigation intervals and seed rate and interaction of these two factors had no significant influence on plant height (Table 1). Even though the difference is nonsignificant, highest seed rate of $150 \mathrm{~kg} \mathrm{ha}^{-1}$ relatively gave increased plant height $(63.57 \mathrm{~cm})$ than $75 \mathrm{~kg} \mathrm{ha}^{-1}(61.70$ $\mathrm{cm})$. The possible reason for increased plant height with increased seed rate might be that plants become thinner and longer to compete the above ground resources specially the solar radiation at the highest seed rate.

In agreement with this result, Haile et al. (2013) also reported in wheat that the height of plants grown at the lowest seed rate was significantly lower than the height of plants grown at higher seed rates.

\section{Spike length}

The statistical analysis results revealed that spike length was not significantly affected by main effects of irrigation interval and seed rate as well as by their interaction. Even though, spike length was not significantly affected by main and interaction effects, the 14 days irrigation interval and the highest seed rate $\left(150 \mathrm{~kg} \mathrm{ha}^{-1}\right)$ gave the lowest spike length (Table 1) which could be due to severe competition for growth resources especially for soil moisture. The result of this study result was also in agreement with the findings of Gafaar (2007) who stated that increasing sowing density from 200 up to 400 grains $\mathrm{m}^{-2}$ significantly decreased spike length. Similarly, Seleiman (2010) reported that the longest spikes were obtained from 250 and 300 grains per $\mathrm{m}^{2}$ while the shortest spikes were recorded by using the highest seeding rate (400 grains per $\left.\mathrm{m}^{2}\right)$.

Similar result was also reported by Khokhar et al. (2010) where spike length was significantly higher with five irrigations (shorter interval) in comparison with other irrigation treatments. Aslam et al. (2014) also reported that the crop receiving five irrigations resulted in maximum spike length of $12.04 \mathrm{~cm}$ while the lowest spike length of $9.64 \mathrm{~cm}$ on average was recorded in plots given three irrigations.

\section{Yield Components}

Number of total tillers

The analysis of variance showed that both the main factors of irrigation interval and seed rate as well as the interaction effect had highly significant $(\mathrm{P}<0.01)$ effect on number of total tillers per $0.5 \mathrm{~m}$ length. In this regard, the highest number of total tillers (54.33) was obtained from the seed rate of $150 \mathrm{~kg} \mathrm{ha}^{-1}$ with irrigation interval of 5 days while the lowest number of total tillers (24.67) was recorded at seed rate of $75 \mathrm{~kg} \mathrm{ha}^{-1}$ and with irrigation interval of 14 days (Table 2). The highest number of total tillers with highest seed rate and frequent irrigation 
might be due to high frequency of irrigation and high plant population that leads to high moisture availability and maximum seed rate that had highest plant population and enhanced number of tillers per unit area. Aslam et al. (2014) reported that wheat crop irrigated five times had maximum number of tillers $\left(402.11 \mathrm{~m}^{-2}\right)$ while the minimum number of tillers $\left(338.00 \mathrm{~m}^{-2}\right)$ was observed in wheat crop kept on three irrigations. Faruque (2002) also reported that the plant growth which depends partly on turgor pressure to sustain cell enlargement, is more sensitive to water supply.

Table 2 Number of total tiller per $0.5 \mathrm{~m}$ row length of wheat as affected by the interaction of irrigation intervals and seed rate

\begin{tabular}{llccc}
\hline $\begin{array}{l}\text { Irrigation interval } \\
\text { (days) }\end{array}$ & \multicolumn{4}{c}{ Seed rate $\left(\mathrm{kg} \mathrm{ha}^{-1}\right)$} \\
& 75 & 100 & 125 & 150 \\
\cline { 2 - 5 } & & & & \\
\hline 5 & $29.00 \mathrm{gh}$ & $34.67 \mathrm{f}$ & $44.67 \mathrm{c}$ & $54.33 \mathrm{a}$ \\
8 & $27.67 \mathrm{hi}$ & $37.00 \mathrm{e}$ & $41.67 \mathrm{~d}$ & $50.00 \mathrm{~b}$ \\
11 & $26.33 \mathrm{i}$ & $35.00 \mathrm{f}$ & $38.00 \mathrm{e}$ & $44.67 \mathrm{c}$ \\
14 & $24.67 \mathrm{j}$ & $29.33 \mathrm{~g}$ & $34.00 \mathrm{f}$ & $40.33 \mathrm{~d}$ \\
LSD (0.05) & 1.520 & & & \\
CV $(\%)$ & 2.45 & & & \\
\end{tabular}

Means with the same letter(s) in the same column and rows of each trait are not significantly different at $5 \%$ probability level, LSD $(5 \%)=$ least significant difference at $5 \%$ probability level, CV $(\%)=$ coefficient of variation in percent and NT $=$ number of tiller per $0.5 \mathrm{~m}$ length.

\section{Number of effective tillers}

The number of effective tillers was significantly $(\mathrm{P}<0.01)$ affected by main effect of irrigation interval and seed rate and their interaction. The highest number of effective tillers (49.33 tillers per $0.5 \mathrm{~m}$ length row) was obtained from the seed rate of $150 \mathrm{~kg} \mathrm{ha}^{-1}$ at five days irrigation interval while lowest number of effective tillers (19.67 tillers in per $0.5 \mathrm{~m}$ length row) was recorded at seed rate of $75 \mathrm{~kg} \mathrm{ha}^{-1}$ and irrigation interval of 14 days (Table 3). The highest number of productive tillers with the highest seed rate and frequent irrigation might be due to the highest plant population per unit area and availability of adequate soil moisture. Likewise, Geleta et al. (2002); and Gafaar (2007) reported that, number of spikes $\mathrm{m}^{-2}$ were increased with increasing seeding rate in wheat. Khan et al. (2004) also reported significantly maximum number of fertile tillers with three irrigation levels.

Table 3 Number of effective tiller per $0.5 \mathrm{~m}$ row length of wheat as affected by the interaction of irrigation intervals and seed rate

\begin{tabular}{lcccc}
\hline $\begin{array}{l}\text { Irrigation interval } \\
\text { (days) }\end{array}$ & \multicolumn{5}{c}{ Seed rate $\left(\mathrm{kg} \mathrm{ha}^{-1}\right)$} \\
& 75 & 100 & 125 & 150 \\
\cline { 2 - 5 } & $28.00 \mathrm{j}$ & $34.67 \mathrm{fg}$ & $41.67 \mathrm{c}$ & $49.33 \mathrm{a}$ \\
\hline 5 & $25.67 \mathrm{k}$ & $34.00 \mathrm{~g}$ & $39.67 \mathrm{~d}$ & $45.00 \mathrm{~b}$ \\
8 & 24.331 & $32.00 \mathrm{~h}$ & $37.33 \mathrm{e}$ & $39.67 \mathrm{~d}$ \\
11 & $19.67 \mathrm{~m}$ & $27.33 \mathrm{j}$ & $31.00 \mathrm{i}$ & $35.00 \mathrm{f}$ \\
14 & & & & \\
& 0.92 & & & \\
LSD $(0.05)$ & 1.61 & & & \\
CV $(\%)$ & & & & \\
\end{tabular}

Means with the same letter(s) in the columns and rows are not significantly different at 5\% probability level, LSD $(5 \%)=$ least significant difference at $5 \%$ probability level, $\mathrm{CV}(\%)=$ coefficient of variation in percent.

\section{Number of kernel per spike}

Analysis of the variance showed that the main effects of irrigation interval and seed rate as well as the interaction had no significant effect on the number of kernels per spike Its value ranged from 27.92 to 30.33 (Table 1). In contrast with this result, Mehrvar and Asadi (2006) reported that by increasing seed rate the number of grains per spike was reduced.

\section{Thousand kernels weight}

The analysis of variance revealed that the interaction of irrigation interval and seed rate had significant $(\mathrm{P}<0.05)$ 
effect on thousand kernels weight. The highest thousand kernels weight (32.20 g) was recorded from seed rate of $100 \mathrm{~kg} \mathrm{ha}^{-1}$ and 11 days irrigation interval whereas the lowest thousand kernels weight $(27.99 \mathrm{~g})$ was recorded at the seed rate of $125 \mathrm{~kg} \mathrm{ha}^{-1}$ and 8 days irrigation interval (Table 4). The lowest kernels weight recorded from higher seed rate might be due to high population density had resulted in competition and thereby might lead to insufficient grain filling. In addition, the presence of higher spike number per rows leads to lower number of kernels per spike and small sized kernels because of inter plant competition to limited resources in the soil.

This result was in agreement with reports of the higher seed rate in bread wheat resulted in decreased 1000 kernels weight (Baloch et al., 2010). Also other authors emphasized the influence of seed rate and plant density on 1000-kernel weight that as seed rate increased also number of spikes $\mathrm{m}^{-2}$ increased, but 1000 kernel weight decreased (Hiltbrunner et al., 2005).

Table 4 Thousand kernel weight (g) of wheat as affected by the interaction of irrigation intervals and seed rate

\begin{tabular}{lllll}
\hline $\begin{array}{l}\text { Irrigation interval } \\
\text { (days) }\end{array}$ & \multicolumn{4}{c}{ Seed rate $\left(\mathrm{kg} \mathrm{ha}^{-1}\right)$} \\
\cline { 2 - 5 } & 75 & 100 & 125 & 150 \\
\hline 5 & $29.07 \mathrm{de}$ & $30.17 \mathrm{a}-\mathrm{d}$ & $31.60 \mathrm{abc}$ & $30.83 \mathrm{a}-\mathrm{d}$ \\
8 & $32.00 \mathrm{ab}$ & $31.67 \mathrm{abc}$ & $27.99 \mathrm{e}$ & $29.33 \mathrm{de}$ \\
11 & $30.60 \mathrm{a}-\mathrm{d}$ & $32.20 \mathrm{a}$ & $30.07 \mathrm{a}-\mathrm{e}$ & $29.73 \mathrm{cde}$ \\
14 & $31.17 \mathrm{a}-\mathrm{d}$ & $30.77 \mathrm{a}-\mathrm{d}$ & $30.30 \mathrm{a}-\mathrm{d}$ & $29.93 \mathrm{~b}-\mathrm{e}$
\end{tabular}

LSD $\quad(0.05) \quad 2.156$

$\mathrm{CV}(\%)$

Means with the same letter(s) in the columns and rows are not significantly different at 5\% probability level, LSD $(5 \%)=$ least significant difference at $5 \%$ probability level and $\mathrm{CV}(\%)=$ coefficient of variation in percent.

\section{Yield and Harvest Index \\ Grain yield}

Analysis of variance showed that irrigation interval and seed rate showed significant effect $(\mathrm{P}<0.01)$ on grain yield. Likewise, interaction of irrigation interval and seed rate also high significantly affected wheat grain yield. The highest grain yield $\left(5.40 \mathrm{tha}^{-1}\right)$ was obtained from seed rate of $100 \mathrm{~kg} \mathrm{ha}^{-1}$ and irrigation interval of $11 \mathrm{days}$ which was statistically at par with the seed rate of $100 \mathrm{~kg} \mathrm{ha}^{-1}$ and irrigation interval of 8 days $\left(5.40 \mathrm{t} \mathrm{ha}^{-1}\right)($ Table 5). On the other hand, the lowest grain yield $\left(1.42 \mathrm{t} \mathrm{ha}^{-1}\right)$ was from the combination of seed rate of 75 $\mathrm{kg} \mathrm{ha}^{-1}$ and irrigation interval of 14 days. The lowest yield at the lowest seed rate might be due to sub-optimal population which could not efficiently utilize the available growth resources. while the lower yields at the highest density might be due to severe competitions among the plants. In very thick densities, falling rate of leaves would increase due to shade and much competition to sun light and environmental conditions, which possibly leading to decreasing rapid early growth, and decreasing grain yield in case of limiting environmental factors such as temperature and sun light. Moreover, the longest duration (14 days) decreased the yield the most due to the obvious moisture stress created.

In conformity with this result, Kumar et al. (2006) and Otteson et al. (2007) reported that increasing seed rate up to $150 \mathrm{~kg} \mathrm{ha}^{-1}$ with optimum fertilizer application resulted in increased grain yield of wheat. Similarly, Baloch et al. (2010) reported that the use of $150 \mathrm{~kg}$ seed ha-1 produced higher grain yield of $5103.3 \mathrm{~kg} \mathrm{ha}^{-1}$ than other seeding rates $\left(100,125,175\right.$, and $\left.200 \mathrm{~kg} \mathrm{ha}^{-1}\right)$.

The study result agreed with the result of Kanwar et al. (2008) who observed that 5 times irrigation resulted in greater density, dry weight and nutrient uptake by wheat compared to twice or three times. Similarly, Wajid et al. (2002) reported that wheat crop produced highest grain yield by applying irrigation at all definable growth stages. Khokhar et al. (2010) also reported that wheat grain yield was higher with five irrigations followed with four and three irrigations. The result of this study has shown that grain yield was significantly reduced under longer irrigation intervals. 
Table 5 Grain yield $\left(\mathrm{t} \mathrm{ha}^{-1}\right)$ of wheat as affected by the interaction of irrigation interval and seed rate

\begin{tabular}{|c|c|c|c|c|c|}
\hline \multirow{2}{*}{\multicolumn{2}{|c|}{$\begin{array}{l}\text { Irrigation interval } \\
\text { (days) }\end{array}$}} & \multicolumn{3}{|c|}{ Seed rate $\left(\mathrm{kg} \mathrm{ha}^{-1}\right)$} & \multirow[b]{2}{*}{150} \\
\hline & & 75 & 100 & 125 & \\
\hline 5 & & $3.60 \mathrm{e}$ & $3.71 \mathrm{de}$ & $3.49 \mathrm{e}$ & $4.94 \mathrm{ab}$ \\
\hline 8 & & 4.54abcd & $5.11 \mathrm{a}$ & $4.09 \mathrm{bcde}$ & $3.95 \mathrm{cde}$ \\
\hline 11 & & $3.70 \mathrm{de}$ & $5.40 \mathrm{a}$ & $3.60 \mathrm{e}$ & $4.84 \mathrm{abc}$ \\
\hline 14 & & $1.42 \mathrm{f}$ & $4.05 \mathrm{bcde}$ & $3.58 \mathrm{e}$ & $3.28 \mathrm{e}$ \\
\hline $\operatorname{LSD}(0.05)$ & 0.77 & & & & \\
\hline $\mathrm{CV}(\%)$ & 11.53 & & & & \\
\hline
\end{tabular}

Means the same letter(s) in columns and rows are not significantly different at 5\% probability level, LSD $(5 \%)=$ least significant difference at $5 \%$ probability level and CV $(\%)=$ coefficient of variation in percent.

\section{Aboveground dry biomass}

Aboveground dry biomass was highly significantly affected by the main effect of irrigation intervals and seed rate and by their interaction. The highest biomass yield $\left(13.34 \mathrm{t} \mathrm{ha}^{-1}\right)$ was obtained from the combination of 11 days irrigation interval and $100 \mathrm{~kg} \mathrm{ha}^{-1}$ seed rate while the lowest dry biomass yield $\left(3.30 \mathrm{t} \mathrm{ha}^{-1}\right)$ was recorded with seed rate of $75 \mathrm{~kg} \mathrm{ha}^{-1}$ and 14 days of irrigation interval (Table 6).

Gafaar (2007) reported the highest value of biological yield with increasing seed rate up to 400 grains $\mathrm{m}^{-2}$ in wheat crop. However, the current result was in contrast with results reported by Allam (2003) where in wheat higher seed rates, higher number of plants and tillers failed to produce higher biomass yield. With regards to the irrigation interval, the result is in line with the findings of Aslam et al. (2014) who reported that wheat crop irrigated five times resulted in significantly maximum biological yield (13732 $\mathrm{kg} \mathrm{ha}^{-1}$ ) while the minimum biological yield $\left(8600 \mathrm{~kg} \mathrm{ha}^{-1}\right)$ was recorded in three irrigations.

Table 6. Aboveground dry biomass $\left(\mathrm{t} \mathrm{ha}^{-1}\right)$ of wheat as affected by the interaction of irrigation interval and seed rate

\begin{tabular}{|c|c|c|c|c|c|}
\hline \multirow{2}{*}{\multicolumn{2}{|c|}{$\begin{array}{l}\text { Irrigation Interval } \\
\text { (days) }\end{array}$}} & \multicolumn{3}{|c|}{ Seed rate $\left(\mathrm{kg} \mathrm{ha}^{-1}\right)$} & \multirow[b]{2}{*}{150} \\
\hline & & 75 & 100 & 125 & \\
\hline 5 & & $8.67 \mathrm{ef}$ & $8.95 \mathrm{ef}$ & $8.21 \mathrm{ef}$ & $12.13 \mathrm{ab}$ \\
\hline 8 & & $11.08 \mathrm{bcd}$ & $12.58 \mathrm{ab}$ & $9.78 \mathrm{de}$ & $9.69 \mathrm{de}$ \\
\hline 11 & & $8.97 \mathrm{def}$ & $13.34 \mathrm{a}$ & $8.57 \mathrm{ef}$ & $12.02 \mathrm{abc}$ \\
\hline 14 & & $3.30 \mathrm{~g}$ & $9.96 \mathrm{cde}$ & $8.62 \mathrm{ef}$ & $7.50 \mathrm{f}$ \\
\hline $\operatorname{LSD}(0.05)$ & 1.758 & & & & \\
\hline C.V(\%) & 10.89 & & & & \\
\hline
\end{tabular}

Means with the same letter(s) in columns and rows are not significantly different at 5\% probability level, LSD $(5 \%)=$ least significant difference at $5 \%$ probability level and $\mathrm{CV}(\%)=$ coefficient of variation in percent.

\section{Straw yield}

Analysis of variance showed that the main effects of irrigation interval and seed rate and their interaction showed highly significant $(\mathrm{P}<0.01)$ effect on grain yield. Like the aboveground dry biomass yield, the highest straw yield $\left(7.95 \mathrm{tha}^{-1}\right)$ was obtained from the combination of 11 days irrigation interval and $100 \mathrm{~kg} \mathrm{ha}^{-1}$ seed rate while the lowest dry biomass yield $\left(1.88 \mathrm{t} \mathrm{ha}^{-1}\right)$ was recorded with seed rate of $75 \mathrm{~kg} \mathrm{ha}^{-1}$ and 14 days of irrigation interval (Table 7). The highest straw yield with the intermediate seed rate could be that higher planting density within limit might produce more total dry matter per unit area. Similar results were obtained by Ali et al. (2004) who found that biological yield was increased with increasing seeding rate in wheat. 
Table 7 Straw yield $\left(\mathrm{t} \mathrm{ha}^{-1}\right)$ of wheat as affected by the interaction of irrigation interval and seed rate

\begin{tabular}{lcccc}
\hline \multirow{2}{*}{$\begin{array}{l}\text { Irrigation interval } \\
\text { (days) }\end{array}$} & \multicolumn{5}{c}{ Seed rate $\left(\mathrm{kg} \mathrm{ha}^{-1}\right)$} \\
\cline { 2 - 5 } & 75 & 100 & 125 & 150 \\
\hline 5 & $5.08 \mathrm{de}$ & $5.24 \mathrm{de}$ & $4.72 \mathrm{de}$ & $7.18 \mathrm{ab}$ \\
8 & $6.53 \mathrm{bc}$ & $7.47 \mathrm{ab}$ & $5.69 \mathrm{~cd}$ & $5.74 \mathrm{~cd}$ \\
11 & $5.27 \mathrm{de}$ & $7.95 \mathrm{a}$ & $4.97 \mathrm{de}$ & $7.18 \mathrm{ab}$ \\
14 & $1.88 \mathrm{f}$ & $5.91 \mathrm{~cd}$ & $5.04 \mathrm{de}$ & $4.22 \mathrm{e}$ \\
LSD (0.05) & 1.01 & & & \\
CV $(\%)$ & 10.64 & & & \\
\end{tabular}

Means with the same letter(s) in columns and rows are not significantly different at 5\% probability level, LSD $(5 \%)=$ least significant difference at $5 \%$ probability level, CV $(\%)=$ coefficient of variation in percent and $\mathrm{t} \mathrm{ha}^{-1}$ $=$ ton per hectare.

\section{Harvest index}

Analysis of variance showed that interaction of irrigation interval and seed rate showed highly significant $(\mathrm{P}<$ $0.01)$ effect on harvest index. The highest harvest index (43.01\%) was recorded from 14 days irrigation interval and $75 \mathrm{~kg} \mathrm{ha}^{-1}$ interaction while the lowest harvest index $(40.29 \%)$ were recorded from the combination of irrigation interval of 11 days and seed rate of $150 \mathrm{~kg} \mathrm{ha}^{-1}$ (Table 8).

The lowest harvest index at the highest seed rate might be due to increased plant height and increased biomass yield rather than grain yield which lead to decrease of harvest index. The result of the current study was consistent with that of Zeng and Shannon (2000) who showed that at high density, carbohydrate supply was limited because of shading among plants and the competition between shoot growth and panicle growth which resulted in the reduction in harvest index with the increases in seeding densities. In contrast, Mollah et al. (2009) reported that seed rate did not have significant effect on harvest index of wheat.

Table 8. Harvest index (\%) of wheat as affected by the interaction of irrigation intervals and seed rate

\begin{tabular}{|c|c|c|c|c|}
\hline \multirow{2}{*}{$\begin{array}{l}\text { Irrigation interval } \\
\text { (days) }\end{array}$} & \multicolumn{3}{|c|}{ Seed rate $\left(\mathrm{kg} \mathrm{ha}^{-1}\right)$} & \multirow[b]{2}{*}{150} \\
\hline & 75 & 100 & 125 & \\
\hline 5 & 41.48def & $41.47 \mathrm{def}$ & $42.42 b$ & $40.77 \mathrm{gh}$ \\
\hline 8 & 41.03fghi & $40.66 \mathrm{ijk}$ & $41.85 \mathrm{~cd}$ & 40.78ghij \\
\hline 11 & $41.26 \mathrm{efg}$ & $40.45 \mathrm{ik}$ & $42.02 \mathrm{bc}$ & $40.29 \mathrm{k}$ \\
\hline 14 & $43.01 \mathrm{a}$ & $40.63 \mathrm{ijk}$ & $41.58 \mathrm{cde}$ & $41.23 \mathrm{efgh}$ \\
\hline $\operatorname{LSD}(0.05)$ & \multicolumn{4}{|l|}{0.38} \\
\hline $\mathrm{CV}(\%)$ & \multicolumn{4}{|l|}{0.54} \\
\hline
\end{tabular}

Means with the same letter(s) in the columns and rows are not significantly different at 5\% probability level, LSD $(5 \%)=$ Least significant difference at $5 \%$ probability level, $\mathrm{CV}(\%)=$ Coefficient of variation in percent and $\mathrm{HI}=$ harvest Index.

\section{Conclusion}

Bread wheat is one of the most important world cereal crops and is a staple food for about one-third of the world's population. In Ethiopia, it is one of the major cereals grown mainly under rainfed conditions. Water is essential for crop production, and any shortage has an impact on final yields. In irrigation practice, over or under irrigation application affects plant growth and yield. A reasonable irrigation scheduling is a key factor to help farmers increase crop yield and save water regarding limited water resources. Moreover, optimum seed rate is one of the most important agronomic practices for maximum yield of crop.

Even though the production of wheat is practiced under irrigation in the study area, its productivity is low due to lack of recommendations on optimum irrigation interval and seed rate. Therefore, this study was conducted during 2019 cropping season to assess the effect of seed rates and irrigation intervals on yield component and yield related traits, and to identify economically feasible seed rate and irrigation interval for increased yield of wheat.

The treatments consisted of four irrigation intervals $(5,8,11$ and 14 days) and four seed rate $(75,100,125$ and $150 \mathrm{~kg} \mathrm{ha}^{-1}$ ) using wheat variety ADEL-6 as the test crop. The experimental design was split plot design with 
three replications using irrigation interval as the main plot factor and seed rate as sub-plot factor.

Results showed non-significant main and interaction effects of the factors on days to heading, days to maturity, plant height, spike length, spikelet's per spike, and number of kernels per spike. On the other hand, the interaction effect of irrigation interval and seed rate had highly significant effect on total tillers, effective tillers, grain yield, aboveground dry biomass yield, straw yield and harvest index. The highest number of total tillers and effective tillers were obtained from the seed rate of $150 \mathrm{~kg} \mathrm{ha}^{-1}$ with irrigation interval of 5 days while the lowest number of total tillers and effective tillers were recorded at seed rate of $75 \mathrm{~kg} \mathrm{ha}^{-1}$ and with irrigation interval of 14 days. In contrast, the highest grain yield $\left(5.40 \mathrm{t} \mathrm{ha}^{-1}\right)$, the highest biomass yield $\left(13.34 \mathrm{t} \mathrm{ha}^{-1}\right)$ and the highest straw yield $\left(7.95 \mathrm{t} \mathrm{ha}^{-1}\right)$ were obtained from seed rate of $100 \mathrm{~kg} \mathrm{ha}^{-1}$ and irrigation interval of 11 days which were statistically at par with the seed rate of $100 \mathrm{~kg} \mathrm{ha}^{-1}$ and irrigation interval of 8 days while the lowest values for these parameters were recorded with seed rate of $75 \mathrm{~kg} \mathrm{ha}^{-1}$ and 14 days of irrigation interval. On the other hand, the list harvest index (43\%) was record from combination of $150 \mathrm{~kg} \mathrm{seed} \mathrm{ha}^{-1}$ and irrigation interval of 14 day.

Thus, from the result of the study, it can tentatively be concluded that use of $100 \mathrm{~kg} \mathrm{ha}^{-1}$ seed rate and irrigation interval ranging from 8 to 11 days can improve the productivity of bread wheat in the study area.

\section{References}

Ali, A G., Zeiton, O E., Bassiauny, A H. and El- Banna, AR Y, 2004. Productivity of wheat cultivars grown at ElKhattara and El-Arish under different levels of planting densities and N-fertilization. Zagazig Journal of Agricultural Research, 31: 1225- 1256.

Allam, A.Y. 2003. Response of three wheat cultivars to split application nitrogen fertilization rates in sandy soils. Australian Journal of Agricultural Science, 1: 1-14.

Aslam, H., M. A. Ansari1, S. K. Baloch, S. U. Baloch, and A. S. Baloch, 2014. Effect of Irrigation Scheduling on the Growth and Harvest Index of Wheat (Triticum aestivum L.) Varities. Persian Gulf Crop Protection, 3(2): 15-29.

Baloch, S. M., I. T. Shah, M. A. Nadim, M. I. Khan, and A. A. Khakwani. 2010. Effect of seeding density and planting time on growth and yield attributes of wheat. The Journal of Animal and Plant Sciences, 20: 239240.

Dereje Gorfu and Yaynu Hiskias, 2000. Yield loss of crops due to diseases in Ethiopia. Ethiopian Journal of Pest Management, 5: 55-67.

FAO (Food and Agricultural Organization).2005: Land Resources Appraisal of Bangladesh for Agricultural Development. Report 2. Agro-eco. Reg. Bang. FAO. Rome, p. 212.

FAO (Food and Agricultural Organization).2013. http://www.faostat.fao.org, May July 2017.

FAOSTAT (Food and Agriculture Organization of the United Nations). 2013. World Crop production data. Available at: (http://www.faostat.fao.org/site. Accessed at July 18, 2010.

Faruque KMO 2002: Growth and yield of wheat cultivars under different soil moisture regimes. M.S Thesis. Dept. Crop Botany, Bangladesh Agric. Univ. Mymensingh.

Gafaar, N A. 2007. Response of some bread wheat varieties grown under different levels of planting density and nitrogen fertilizer. Minufiya Journal of Agriculture, 32: 165-183.

Geleta, B., Atak, M., Baenziger, P. S., Nelson, L A., Baltenesperger, D. D., Eskridge, K M., Shipman, M J. and Shelton, D R., 2002. Seeding rate and genotype effect on agronomic performance and end-use quality of winter wheat. Journal of Crop Science, 42:827-832.

Haile Deressa, Nigussie-Dechassa, Abdo W and Girma F. 2013. Seeding rate and genotype effects on agronomic performance and grain protein content of durum wheat (Triticum turgidum L. var. durum) in South-Eastern Ethiopia. Afirican Journal of Food, Agriculture, Nutrition and Development, 13 (3).

Hiltbrunner, J., M. Liedgens, P. Stamp, and B. Streit. 2005. Effects of row spacing and liquidmanure on directly drilled winter wheat in organic farming. European Journal of Agronomy, 22: 441- 447.

Hussain MI and SH Shah Growth, yield and quality response of three wheat (Triticum aestivum L.) varieties to different levels of N, P and K. Int. J.of Agri. and Bio. 2002; 4(3): 362-364.

Iqtidar H, Muhammad AK and AK Ejaz.2006. Bread wheat varieties as influenced by different nitrogen levels. $J$. Zhejiang Univ. Sci., 7(1): 70- 78.

Khan M.B, Ali H, Asif M. 2004. The response of different irrigation levels of growth and yield of different wheat (Triticum aestivum L.) cultivars. Journal of Research Science, 13(1):71-75.

Kanwar S, Malik RK, Yadav SK, Ashok Y, Sher Y S, Sangwan NK. 2008. Effect of irrigation levels and chlorsulfuron doses on weed infestation and yield of wheat. (Triticum aestivum). Annual Agricultural Research, 11(2): 147-150.

Khokhar, B., I. Hussain and Z. Khokhar, 2010. Effect of Different Irrigation Frequencies on Growth and Yield of Different Wheat Genotypes in Sindh. Pakistan J. Agric. Res., 23 (3-4): 108-112.

Kumar, R., R.K. Nanwal and Agarwal, S.K. 2006. NPK content and uptake as affected by planting systems, seed rates and N levels in wheat (Triticum aestivum L.). Haryana Agricultural. University Journal. Resource, 36 
(2): 93-96.

Lantican, M.A., Dubin, M.J., and Morris, M.L. 2005. Impacts of International Wheat Breeding Research in the Developing World, 1988-2002. Mexico, D.F.: CIMMYT

MoA (Ministry of Agriculture). 2009. Ministry of Agriculture. Animal and Plant Health Regulatory Directorate. Crop variety register, Issue No. 12. Addis Ababa, Ethiopia.

MoA (Ministry of Agriculture). 2012. Ministry of Agriculture. Animal and Plant Health Regulatory Directorate. Crop variety register, Issue No. 15. Addis Ababa, Ethiopia.

Mollah M.I, Bhuiya M.S, Kabir M.H, 2009. Bed Planting -a new crop establishment method for wheat in ricewheat cropping system, Journal of Agriculture and Rural Development, 7(1-2): 23-31.

Otteson, B.N., M. Mergoum, and J.K. Ransom. 2007. Seeding rate and nitrogen management effect on spring wheat yield and yield components. Agronomy Journal, 99: 1615-1621.

Ozturk A, Aydin F (2004) Effect of water stress at various stages on some quality parameters of winter wheat. Crop Sci 190: 93-99.

Richards RA, Rebetzke GJ, Condon AG, and Herwaarden, AF. 2002. Breeding opportunities for increasing the efficiency of water use and crop yield in temperate cereals. Crop Science, 42: 111-131.

Seleiman, M. 2010. Effect of seeding rates on productivity, technological and rheological characteristics of bread Wheat (Triticum aestivum L.). International Journal of Current Research, 4: 75-81.

Solomon KF, Labuschagen MT, Bennie ATP. 2003. Responses of Ethiopian durum wheat genotypes to drought stress. South African J Plant Soil,20: 55-58.

Wajid A, Hussain A, Maqsood M, Ahmad Awais M. 2002 Influence of sowing date and irrigation levels on growth and grain yield of wheat. Pakistan Journal of Agriculture, 39(1): 22-24.

White, E.M. (2001). Spring wheat growth at high and low soil water with constricted upper roots. Soil Sci., 143(1): 44-49.

Zeng, L. and M. C. Shannon, 2000. Effects of Salinity on Grain Yield and Yield Components of Rice at Different Seeding Densities. Journal of Agronomy, 1 (92): 418-423.

\section{Author Profile}

The author, Nuru Seid, joined in University of Gondar in 2011 and graduated in July 2013 with BSc. degree in Plant Sciences. In December 2014, the Ministry of Agriculture at Gewane Agricultural Technical Vocational Education Training (GATVET) College employed him. After working for three years as a plant science instructor, in July 2016, he joined the postgraduate program at Haramaya University, School of Plant Science, and graduated in February 2019 with Master of Science degree in Agronomy. Now the author is Plant Science Lecturer in Mekdela Amba University, Ethiopia. 